\title{
Caspase-8 Is an Effector in Apoptotic Death of Dopaminergic Neurons in Parkinson's Disease, But Pathway Inhibition Results in Neuronal Necrosis
}

\author{
Andreas Hartmann, ${ }^{1}$ Jean-Denis Troadec, ${ }^{1}$ Stéphane Hunot, ${ }^{1}$ Kristy Kikly, ${ }^{2}$ Baptiste A. Faucheux, ${ }^{1}$ \\ Annick Mouatt-Prigent, ${ }^{1}$ Merle Ruberg, ${ }^{1}$ Yves Agid, ${ }^{1}$ and Etienne C. Hirsch ${ }^{1}$ \\ 1/nstitut National de la Santé et de la Recherche Médicale U289, Hôpital de la Salpêtière, 75013 Paris, France, and \\ 2SmithKline Beecham Pharmaceuticals, King of Prussia, Pennsylvania 19406-0939
}

\begin{abstract}
Caspase-8 is a proximal effector protein of the tumor necrosis factor receptor family death pathway. In the present human postmortem study, we observed a significantly higher percentage of dopaminergic (DA) substantia nigra pars compacta neurons that displayed caspase-8 activation in Parkinson's disease (PD) patients compared with controls. In an in vivo experimental PD model, namely subchronically 1,2,3,6-tetrahydropyridinetreated mice, we also show that caspase- 8 is indeed activated after exposure to this toxin early in the course of cell demise, suggesting that caspase- 8 activation precedes and is not the
\end{abstract}

consequence of cell death. However, cotreatment of 1-methyl4-phenylpyridinium-intoxicated primary DA cultures with broad-spectrum and specific caspase-8 inhibitors did not result in neuroprotection but seemed to trigger a switch from apoptosis to necrosis. We propose that this effect is related to ATP depletion and suggest that the use of caspase inhibitors in pathologies linked to intracellular energy depletion, such as PD, should be cautiously evaluated.

Key words: Parkinson's disease; caspase-8; apoptosis; necrosis; ATP; MPTP
Several recent human postmortem studies have suggested that dopaminergic (DA) neurons die by apoptosis in Parkinson's disease (PD) (for review, see Hartmann and Hirsch, 2000). Apoptosis is also observed in in vivo and in vitro models of PD based on the toxicity of 1-methyl-4-phenylpyridinium $\left(\mathrm{MPP}^{+}\right)$and 6-hydroxydopamine for DA neurons (Hartley et al., 1994; Mochizuki et al., 1994; Tatton and Kish, 1997; Dodel et al., 1998, 1999; Ochu et al., 1998; Spooren et al., 1998; Takai et al., 1998; Lotharius et al., 1999). Apoptosis may reflect a primary disease mechanism in $\mathrm{PD}$, i.e., inappropriate excessive apoptosis, or appropriate apoptosis as the consequence of cell damage subsequent to oxidative stress, iron accumulation, mitochondrial complex I insufficiency, excitotoxicity, nitric oxide formation, inflammatory processes, and other cellular abnormalities described in PD (Marsden and Olanow, 1998).

In PD patients, this apoptotic cell death of DA neurons may be mediated by the tumor necrosis factor (TNF) receptor pathway. TNF receptor 1 (TNFR1)-positive DA neurons can be detected throughout the substantia nigra pars compacta ( $\mathrm{SNpc}$ ) of control and parkinsonian subjects, whereas the density of TNF- $\alpha$-positive glial cells in the SNpc is substantially higher in PD patients than controls, suggesting that the TNF receptor/ligand system may participate in the degeneration of nigral DA neurons in PD (Boka et al., 1994).

\footnotetext{
Received Nov. 17, 2000; revised Jan. 18, 2001; accepted Jan. 19, 2001.

This work was supported by the Institut National de la Santé et de la Recherche Médicale and the National Parkinson Foundation Inc. (Miami, FL). A.H. is a postdoctoral fellow of the Deutsche Forschungsgemeinschaft and the Fondation pour la Recherche Médicale. J.D.T. is supported by l'Association pour la Recherche contre le Cancer (Paris, France). S.H. is a fellow of the Fondation pour la Recherche Médicale. B.A.F. is supported by the Association Claude Bernard pour le Développement des Recherches Biologiques et Médicales dans les Hôpitaux de l'Assistance Publique à Paris.

Correspondence should be addressed to Dr. Etienne C. Hirsch, Institut National de la Santé et de la Recherche Médicale U289, Hôpital de la Salpêtrière, 47 Boulevard de l'Hôpital, 75013 Paris, France. E-mail: hirsch@ccr.jussieu.fr. Copyright (C) 2001 Society for Neuroscience $0270-6474 / 01 / 212247-09 \$ 15.00 / 0$
}

This line of argument is supported by recent postmortem and in vitro findings that the release of astrocytic cytokines, such as TNF- $\alpha$, interleukin-1, and interferon- $\gamma$, may contribute to DA cell death in PD (Hunot et al., 1999). Previously, nuclear translocation of nuclear factor- $\kappa \mathrm{B}(\mathrm{NF}-\kappa \mathrm{B})$, which can be triggered by the TNF receptormediated pathway, was demonstrated to be increased 70 -fold in DA SNpc neurons of PD patients compared with controls (Hunot et al., 1997). It has also been shown that the levels of TNF- $\alpha$ are significantly increased in the striatum and CSF of patients with PD (Mogi et al., 1994) and that the levels of TNFR1 are increased in the SNpc of PD patients (Mogi et al., 2000).

TNF- $\alpha$ induces trimerization of TNFR1 upon binding. Through the adaptor proteins TNF receptor-associated death domain (TRADD) and FAS-associated death domain (FADD), caspase-8 is autoproteolitically activated (Schulze-Osthoff et al., 1998). Caspase-8 may in turn either cleave effector caspases, such as caspase-3, directly or amplify the death signal through translocation of BID, a proapoptotic member of the Bcl-family, to the mitochondria and the subsequent release of cytochrome $\mathrm{c}$ from the mitochondrial intermembrane space into the cytosol (Green, 1998). Cytochrome c release eventually also triggers caspase-3 activation, which plays an important role in cell death of DA SNpc neurons in PD (Hartmann et al., 2000). Finally, caspase-8 can also be activated downstream of mitochondrial cytochrome c release (Granville et al., 1998; Slee et al., 1999), possibly to amplify the BID-induced cytochrome c release.

With regard to the downstream signaling pathway of TNF- $\alpha$, we therefore sought to investigate the potential contribution of the apical intracellular proapoptotic effector of the TNF-receptor family, caspase-8, to the death of DA neurons in PD.

\section{MATERIALS AND METHODS}

Patients and human brain tissue. Mesencephalons were obtained at autopsy from four individuals with no known history of psychiatric or 
neurological disorders (control group) and from four patients with histologically confirmed PD (PD group) for quantitative analysis of caspase- 8 activation using the antibody raised against activated caspase- 8 (SK440) (Velier et al., 1999). Four to five sections covering the whole extent of the SNpc from its rostral to its caudal pole were used. For analysis of the locus ceruleus (LC), one level per subject was chosen. All patients had a clinical history compatible with a diagnosis of PD and were responsive to L-3,4-dihydroxyphenylalanine (L-DOPA) treatment. They had moderate to severe illness with marked bradykinesia, rigidity, and tremor (Hoehn and Yahr stages III-IV). Age at death and time interval from death to tissue fixation did not differ significantly between controls $(72.0 \pm 13.7$ years and $33.4 \pm 7.8 \mathrm{hr}$, respectively) and PD patients $(76.8 \pm 7.2$ years and $25.5 \pm 10.2 \mathrm{hr}$, respectively). Within $2 \mathrm{hr}$ of autopsy, tissue was dissected and processed as described previously (Hirsch et al., 1988).

1,2,3,6-Tetrahydropyridine-intoxicated mice. All experimental protocols were approved by our local institutional review committee and performed in accordance with the guidelines issued by the French Ministry for Research. Mice were subchronically intoxicated with 1,2,3,6tetrahydropyridine (MPTP) as described previously (Tatton and Kish, 1997). In brief, 8 -week-old male C57BL/6 mice $(n=5)$ were injected intraperitoneally with MPTP at $30 \mathrm{mg} \cdot \mathrm{kg}^{-1} \cdot \mathrm{d}^{-1}$ over a period of $5 \mathrm{~d}$. A control group $(n=5)$ was injected with equivalent volumes of $\mathrm{NaCl}$ $0.9 \%$. One day after the last MPTP or $\mathrm{NaCl}$ injection, the animals were anesthetized and decapitated, and the SN was removed as described previously (Spampinato et al., 1988). Tissue was immediately shockfrozen until further processing. For SK440 immunohistochemistry, a control group $(n=6)$ and an MPTP group $(n=6)$ were treated as described above. One day after the last MPTP or NaCl injection, the animals were anesthetized and transcardially perfused with $4 \%$ paraformaldehyde. Brains were removed from the skull, post-fixed for $24 \mathrm{hr}$ in $4 \%$ paraformaldehyde, and washed three times in $10 \%$ saccharose for 24 hr. They were then frozen by immersion in isopentane and stored at $-80^{\circ} \mathrm{C}$. Subsequently, $25-\mu \mathrm{m}$-thick coronal sections were cut over the whole span of the mesencephalon.

Primary cultures of rat mesencephalon. Rat embryos were recovered at day 15.5 from gestating Wistar rats (Center d'Elevage R. Janvier, Le Genest St. Isles, France). The ventral midbrain was dissected as described previously (Michel and Agid, 1996; Franke et al., 2000), mechanically dissociated, and plated on polyethylene imine $(1 \mathrm{mg} / \mathrm{ml})$ precoated culture plates (24 wells) or mounted on Falcon glass culture slides (Becton Dickinson, Franklin Lakes, NJ) in N5 medium supplemented with $5 \%$ horse serum and $2.5 \%$ fetal calf serum, at a density of $0.8-1.2 \times$ $10^{5}$ cells $/ \mathrm{cm}^{2}$. After $2 \mathrm{~d}$, the medium was switched to a serum-free medium composed of Ham's nutrient mixture F12-Minimal Essential Medium 1:1 and supplemented with $25 \mu \mathrm{g} / \mathrm{ml}$ insulin, $100 \mu \mathrm{g} / \mathrm{ml}$ holotransferrin, $20 \mathrm{nM}$ progesterone, $60 \mu \mathrm{M}$ putrescine, $30 \mathrm{~mm}$ sodium selenite, $25 \mathrm{~mm}$ glucose, $2 \mathrm{~mm}$ glutamine, $25 \mathrm{~mm} \mathrm{NaHCO}_{3}$, and $15 \mathrm{~mm}$ HEPES, to stop astrocyte proliferation (Michel and Ruberg, 1999). Six days later, the cultures were treated as described previously (Michel and Agid, 1992) with cell-permeant $\mathrm{MPP}^{+}(3 \mu \mathrm{M}$; Sigma, St. Louis, $\mathrm{MO})$ alone or cotreated with the broad-spectrum caspase inhibitor $\mathrm{N}$-benzyloxycarbonyl-Val-Ala-Asp-fluoromethyl ketone (zVAD-fmk) [100 $\mu \mathrm{M}$; Calbiochem (Nottingham, UK) catalog \#627610], the caspase-8 inhibitor z-Ile-Glu(OMe)-Thr-Asp(OMe)-fluoromethyl ketone (zIETDfmk) (100 $\mu \mathrm{M}$; Calbiochem catalog \#218759), and/or glucose (75 mM; final glucose concentration, $100 \mathrm{mM}$ ). The $\mathrm{MPP}^{+}$concentration of $3 \mu \mathrm{M}$ was chosen after also testing a $1 \mu \mathrm{M}$ concentration used by other groups (Dodel et al., 1998; Lotharius et al., 1999), which, however, did not induce a sufficient cell death rate $(>50 \%$ after $72 \mathrm{hr})$. To determine activity of the caspase inhibitors used, they were tested previously in appropriate caspase assays (Calbiochem caspase-3 assay kit \#235418 for zVAD-fmk; Calbiochem caspase-8 assay kit \#218770 for zIETD-fmk). All cell culture experiments were performed at least in triplicate.

Western immunoblotting. To positively detect the cleaved p20 fragment of caspase-8 using the SK440 polyclonal rabbit antibody (Velier et al., 1999) raised against the $\mathrm{p} 20 / \mathrm{p} 10$ caspase- 8 cleavage product purified from Escherichia coli, $15 \mu \mathrm{g}$ of Jurkat cell lysates (Transduction Laboratories, Lexington, KY) were preincubated with $500 \mathrm{ng}$ of recombinant caspase-8 (PharMingen, San Diego, CA) for $60 \mathrm{~min}$ at $37^{\circ} \mathrm{C}$ or left untreated. The proteins were separated by PAGE and transferred onto nitrocellulose membranes. The membranes were blocked in the presence of $5 \%$ nonfat milk, incubated for $48 \mathrm{hr}$ at $+4^{\circ} \mathrm{C}$ with the SK440 antibody (1:2000). The membrane was then incubated with anti-rabbit secondary antibody conjugated with horseradish peroxidase (1:2500; Amersham
Pharmacia Biotech, Les Ulis, France) at room temperature for $2 \mathrm{hr}$. The reaction was visualized using an ECL detection kit (Amersham Pharmacia Biotech).

Immunohistochemistry. For the postmortem analysis, free-floating 40$\mu \mathrm{m}$-thick mesencephalon sections were pretreated as described previously (Hirsch et al., 1988) and incubated with the SK440 antibody (1:2000, $48 \mathrm{hr}$ at $\left.4^{\circ} \mathrm{C}\right)$. The sections were then incubated in biotinylated goat anti-rabbit IgG. Staining was revealed by the ABC method (Vector Laboratories, Burlingame, CA) and developed using 0.04\% (w/v) diaminobenzidine in acetate buffer with $1.28 \%$ (w/v) nickel ammonium sulfate to produce a blue reaction product, as described previously (Hunot et al., 1997).

For the mouse sections, immunohistochemistry was performed on $25-\mu \mathrm{m}$-thick free-floating sections. Sections were washed three times in $0.1 \mathrm{M}$ PBS, incubated in $4 \%$ albumin for $60 \mathrm{~min}$, washed three times in 0.1 M PBS, and incubated with the SK440 antibody $\left(1: 2000,48 \mathrm{hr}\right.$ at $\left.4^{\circ} \mathrm{C}\right)$. Staining was revealed by the ABC method (Vector Laboratories) with 3,3'-diaminobenzidine as the peroxides substrate.

In primary cell cultures, after fixation with $4 \%$ formaldehyde, DA neurons were identified with a monoclonal tyrosine hydroxylase $(\mathrm{TH})$ antibody (Boehringer Mannheim, Mannheim, Germany) at $1: 250$ at $4^{\circ} \mathrm{C}$ for $24 \mathrm{hr}$ and subsequently incubated with a biotinylated goat anti-mouse $\operatorname{IgG} 2 \mathrm{a}(1: 100,2 \mathrm{hr}$ at room temperature; Amersham Pharmacia Biotech). Staining was revealed by the ABC method (Vector Laboratories) with 3,3-diaminobenzidine as the peroxidase substrate (Michel and Agid, 1992). For the fluorescent TH labeling experiments, cultures were incubated with anti-TH $\left(1: 250\right.$ at $4^{\circ} \mathrm{C}$ for $\left.48 \mathrm{hr}\right)$. TH was revealed using an anti-mouse antibody coupled to tetramethylrhodamine isothiocyanate (TRITC) (1:100, $2 \mathrm{hr}$ at room temperature; Dako, Glostrup, Denmark). The cell-permeant fluorescent marker Hoechst 33258 (1 $\mu \mathrm{M}$; Boehringer Mannheim) was added to the cultures for $15 \mathrm{~min}$ at room temperature to assess the morphology of normal and apoptotic cells (i.e., condensed or fragmented).

Terminal deoxynucleotidyl transferase-mediated biotinylated UTP nick end labeling assays. The Apoptag fluorescein in situ detection kit (catalog \#S7110; Intergen, Purchase, NY) was used on primary mesencephalic cultures untreated or treated with $3 \mu \mathrm{M} \mathrm{MPP}{ }^{+}, 3 \mu \mathrm{M} \mathrm{MPP}{ }^{+}-100 \mu \mathrm{M}$ zVAD-fmk, or $3 \mu \mathrm{M} \mathrm{MPP}{ }^{+}-100 \mu \mathrm{M}$ zIETD-fmk as described previously, according to the instructions of the manufacturer, with minor modifications. Instead of proteinase $\mathrm{K}$, cultures were permeabilized with Triton $0.1 \% \mathrm{X}-100$ for $15 \mathrm{~min}$ at room temperature. Subsequent to the assay, cultures were incubated with anti-TH antibodies, revealed with antimouse antibodies coupled to TRITC, and counterstained with Hoechst 33258 (Whiteside and Munglani, 1998).

Regional quantification and image analysis. For activated caspase-8 staining using the SK440 antibody in the human postmortem mesencephalon, immunoreactive melanized neurons were counted in the SNpc and the LC using a computer-based image analysis system (Biocom, Les Ulis, France). The total number of DA neurons in the mesencephalon was estimated as described previously (Hirsch et al., 1988). Based on these estimates, the total number of SK440-positive neurons in the SNpc was estimated using the same method, and the ratio between the estimated total numbers of SK440- and TH-positive neurons was calculated. For SK440 staining in the mouse SNpc, the SNpc was delineated on adjacent sections stained with anti-tyrosine hydroxylase and SK-440-positive neurons with DA morphology counted within these limits.

Cell cultures were analyzed by phase-contrast and standard epiillumination fluorescence microscopy and by computer-assisted image analysis (Imstar, Paris, France). For the TH-positive cell count, cell cultures were counted at $10 \times$ covering eight fields in horizontal axis and eight fields in vertical axis per well. To assess cell morphology, cell cultures were analyzed at $100 \times$ on a Zeiss (Oberkochen, Germany) Axioplan 2 microscope.

Measurement of caspase- 8 activity. Protease activity of caspase- 8 in extracts of mouse mesencephalon was measured using a caspase- 8 assay kit (Calbiochem catalog \#218770) in accordance with the instructions of the manufacturer. In brief, the conversion factor was first determined by calculating the extinction coefficient of $p$-nitroaniline $(p \mathrm{NA})$ in the calibration standard. Then, three samples of pooled tissue per condition (control vs MPTP) were lysed in assay buffer containing 0.1\% 3-[(3cholamidopropyl)dimethylammonio]-1-propanesulfonate, $10 \mathrm{~mm}$ dithiothreitol, $1 \mathrm{~mm}$ EDTA, $10 \%$ glycerol, and $100 \mathrm{~mm} \mathrm{NaCl} 0.9 \%$ (final volume per sample, $75 \mu \mathrm{l}$ ), transferred to a 96-well microtiter plate, and incubated with $15 \mu \mathrm{l}$ of caspase- $8(2 \mathrm{U} / \mu \mathrm{l})$ at room temperature for 10 min. The reaction was started by addition of $10 \mu$ l of colorimetric 


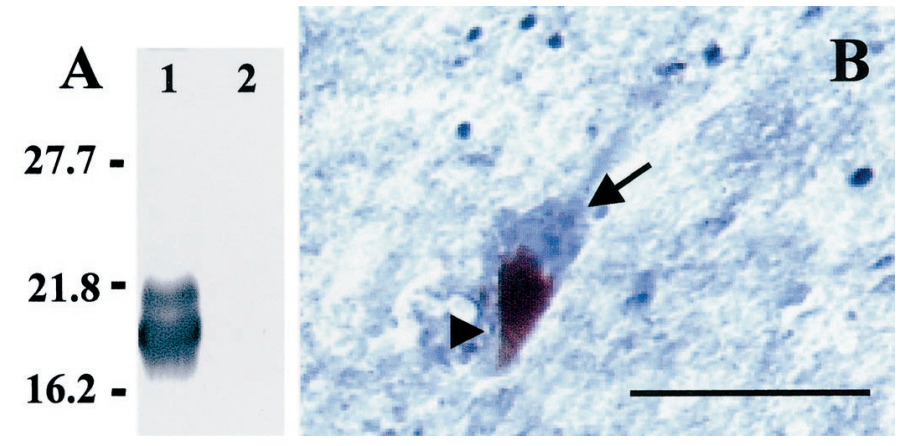

Figure 1. Characterization of SK440 staining. $A$, Specificity of the SK440 polyclonal rabbit antibody. Western immunoblot of activated caspase-8 from $15 \mu \mathrm{g}$ of Jurkat cell lysate preincubated with $500 \mathrm{ng}$ of recombinant caspase- 8 for $60 \mathrm{~min}$ at $37^{\circ} \mathrm{C}$ (lane 1) or left untreated (lane 2) after SDS-PAGE. Molecular weight markers in the first lane are given in kilodaltons and allow identification of the p20 caspase-8 subunit in lane 1 . $B$, High-power photomicrograph showing cytosolic SK440-immunostaining of SNpc neuromelanin-containing neurons in sections of PD SNpc. Arrowhead, Neuromelanin; arrow, SK440 staining. Scale bar, $20 \mu \mathrm{m}$.

granzyme B substrate I (Ac-IETD-pNA). Absorbance was read at 405 $\mathrm{nm}$ at $5 \mathrm{~min}$ intervals over $30 \mathrm{~min}$. The amount of released caspase- 8 was expressed in picomoles per minute. All measurements were performed on an MR 5000 spectrometer (Dynatech, Chantilly, VA).

Measurement of $\left[{ }^{3} \mathrm{H}\right] \mathrm{DA}$ uptake. The functional integrity of DA neurons was evaluated by their ability to accumulate tritiated DA by active transport, as described previously (Michel et al., 1997). In brief, cells were preincubated for $10 \mathrm{~min}$ with $500 \mu \mathrm{l}$ of DA uptake solution (PBS containing $5 \mathrm{~mm}$ glucose and $100 \mu \mathrm{M}$ ascorbic acid). The reaction was initiated by adding $50 \mathrm{~nm}\left[{ }^{3} \mathrm{H}\right] \mathrm{DA}$ (40 Ci/mol; Amersham Pharmacia Biotech) to the cultures and terminated after $15 \mathrm{~min}$ by three rapid PBS washes. Cells were scraped off the culture well and counted by liquid scintillation spectroscopy. Blank values were obtained in the presence of $3 \mu \mathrm{M}$ mazindol (Sigma).

Measurement of ATP/ADP levels. ATP/ADP levels were determined by the lucerin-luciferase method using the Apoglow kit (Lumitech; Alexis Biochemicals, San Diego, CA) in accordance with the instructions of the manufacturer. In brief, $72 \mathrm{hr}$ after treatment, cells were incubated with $100 \mu \mathrm{l}$ of nucleotide releasing agent per well and allowed to equilibrate at room temperature for $5 \mathrm{~min}$. Cells were then scraped off the culture well and transferred to an opaque white microplate. The reaction was started by adding $20 \mu \mathrm{l}$ of nucleotide monitoring reagent per well. Luminescence was read with a Spectra Max Gemini spectrofluorimeter (Molecular Devices, Sunnyvale, CA). The first reading determined ATP concentrations ("reading A"). After $5 \mathrm{~min}, 20 \mu \mathrm{l}$ of ADP converting reagent was added per well, and luminescence was read ("reading B"). The final reading was performed 5 min later ("reading C"). ADP concentrations were calculated as $\mathrm{C}-\mathrm{B}$. ADP/ATP ratios were calculated as $(\mathrm{C}-\mathrm{B}) / \mathrm{A}$.

Statistical analysis. Data are presented as mean \pm SEM. Intergroup differences (control vs PD or treatment) were compared by one-way ANOVAs for the postmortem analysis (pathology) and cultures (treatment) or, in the event of failure in normality test, by Mann-Whitney rank sum test. The null hypothesis was rejected at an $\alpha$ risk of $5 \%$.

\section{RESULTS}

\section{Specificity of antibodies directed the cleaved caspase- 8 p20 subproduct (SK440)}

To test the specificity of the SK440 antibody against activated caspase-8, Jurkat cell lysates were preincubated with human recombinant caspase-8. After incubation with the SK440 antibody, the cleaved caspase- 8 p20 cleavage product could readily be detected (Fig. 1A, lane 1), whereas untreated Jurkat cell lysates were not immunoreactive for the SK440 antibody (Fig. 1A, lane 2). Furthermore, on tissue sections, the intensity of staining with both antibodies decreased with lower antibody dilutions, and no staining was observed when the primary antibody was omitted (data not shown).

\section{Immunohistochemical detection of activated caspase- 8 in control and parkinsonian mesencephalon}

At the cellular level, both melanized neurons and glial cells were stained. Whereas TH immunoreactivity was observed in cell perikarya and dendrites, SK440 immunoreactivity was confined to the cytosol of the neuronal perikarya (Fig. 1B). Among melanized neurons, staining intensity was intense in the SNpc and moderate in the ventral tegmental area. SK440-immunoreactive glial cells were also observed in all mesencephalic subregions.

\section{Caspase-8 activation is observed almost exclusively in parkinsonian SNpc DA neurons but not in LC DA neurons}

In the SNpc, based on the estimated total number of melanized and SK440-positive neurons, the proportion of DA neurons that were SK440-positive was significantly higher in PD patients than in control subjects $\left(\mathrm{PD}, 1.45 \times 10^{-2} \pm 1.05 \times 10^{-2} \%\right.$; controls, $1.075 \times 10^{-4} \pm 0.692 \times 10^{-4} \%$; Mann-Whitney rank sum test; $p=0.029)$. Therefore, although SK440-positive melanized neurons were scarce in both groups, this percentage was 1350 times higher in PD patients than in the control group. In contrast, melanized LC neurons did not display any immunoreactivity for activated caspase- 8 in either the control or the PD group.

\section{Release of activated caspase- 8 is increased in the SNpc of mice intoxicated with MPTP}

We next tried to determine in an animal model of PD, namely C57BL/6 mice intoxicated with MPTP $\left(30 \mathrm{mg} \cdot \mathrm{kg}^{-1} \cdot \mathrm{d}^{-1}\right.$ over $5 \mathrm{~d}$ ), whether release of activated caspase- 8 was altered by this neurotoxin compared with $\mathrm{NaCl} 0.9 \%$-treated controls. A previous study suggested that, under this intoxication protocol, DA neurons die by apoptosis (Tatton and Kish, 1997). Experiments were performed on homogenates of SNpc from MPTP-treated mice and control mice $1 \mathrm{~d}$ after intoxication, because at this time, according to Tatton and Kish (1997), a maximum number of apoptotic cells can be observed, although cell death continues until day 7 after intoxication. A significantly increased $(p<0.05)$ rate of caspase- 8 activation was observed in MPTP-treated mice compared with saline-treated animals (controls, $42.4 \pm 1.0 \mathrm{pmol} /$ min; MPTP-treated mice, $50.1 \pm 1.6 \mathrm{pmol} / \mathrm{min} ;+18.2 \%)$. Using the SK440 antibody on SNpc sections of mice treated as described above, no cleaved caspase-8-positive neurons were detected in control SNpc, whereas an average of $0.33 \pm 0.21$ cleaved caspase-8 neurons per section were detected in the SNpc of MPTP-treated mice; this difference, however, was not significant $(p=0.18)$.

\section{Primary DA cell cultures treated with $\mathrm{MPP}^{+}$are not protected by caspase inhibitors, as reflected by TH cell count}

Next, primary cultures of rat mesencephalon were treated with 3 $\mu \mathrm{MPP}^{+}$, because previous studies have shown that low concentrations of $\mathrm{MPP}^{+}(1-10 \mu \mathrm{M})$ induce the death of DA neurons with morphological features of apoptosis, whereas higher concentrations induce necrosis (Mochizuki et al., 1994; Dodel et al., 1998). Cultures treated with $\mathrm{MPP}^{+}$were coincubated with 100 $\mu \mathrm{M}$ zVAD-fmk, a broad-spectrum caspase inhibitor with relative specificity for caspase-2, caspase-3, and caspase-7, and $100 \mu \mathrm{M}$ zIETD-fmk with relative specificity for caspase-8 (Garcia-Calvo et al., 1998). Cultures were stained for TH at 12, 24, and $72 \mathrm{hr}$ after initiation of treatment. At $12 \mathrm{hr}$, no difference in $\mathrm{TH}$ cell 


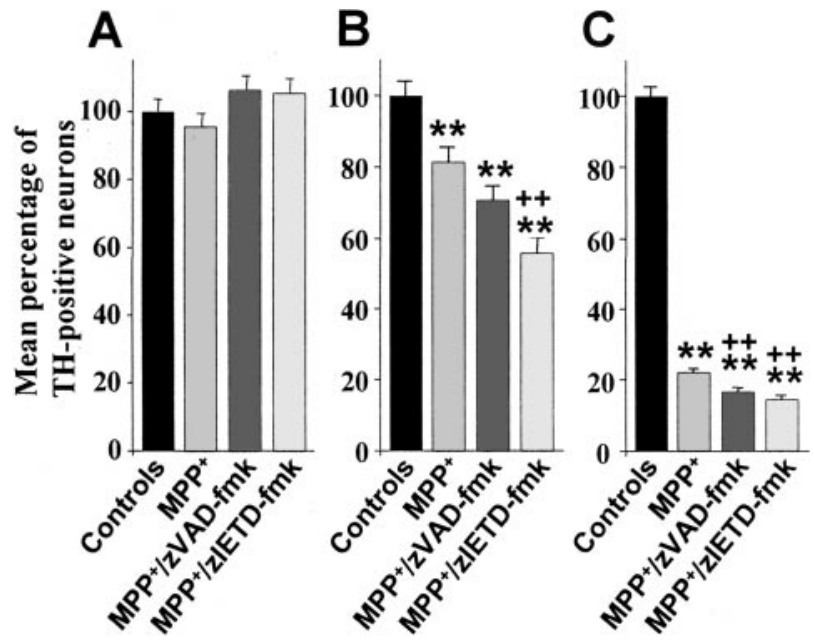

Figure 2. Mean percentage of TH-positive neurons in primary cultures of rat mesencephalic neurons. Cultures were treated with $3 \mu \mathrm{M} \mathrm{MPP}{ }^{+}, 3$ $\mu \mathrm{M} \mathrm{MPP}{ }^{+}$, and $100 \mu \mathrm{M} \mathrm{zVAD-fmk,} \mathrm{or} 3 \mu \mathrm{M} \mathrm{MPP}{ }^{+}$and $100 \mu \mathrm{M}$ zIETDfmk, and fixed after $12(A), 24(B)$, and $72(C)$ hr. Mean total number of TH-positive neurons per control well were $761 \pm 43.7$ (12 hr), $664 \pm 36.2$ $(24 \mathrm{hr})$, and $769 \pm 45.1(72 \mathrm{hr}) . * * p<0.001$ compared with control cultures. $++p<0.001$ compared with $\mathrm{MPP}^{+}$cultures.

count was observed under the different conditions (Fig. 2A). At $24 \mathrm{hr}$, a significant decrease in $\mathrm{TH}$ cell count was observed in the $\mathrm{MPP}^{+}$condition. TH cell count decreased even further in cultures cotreated with zVAD-fmk or with zIETD-fmk. Furthermore, the percentage of TH-positive neurons was significantly decreased in the zIETD-fmk condition compared with the MPP ${ }^{+}$ conditions at this time point (Fig. 2B). Finally, at $72 \mathrm{hr}$, TH cell counts were maximally decreased in the $\mathrm{MPP}^{+}$conditions compared with the control cultures. As at $24 \mathrm{hr}$, the percentage of TH-positive cells decreased even more dramatically when cultures were cotreated with zVAD-fmk or zIETD-fmk. Furthermore, the differences between the $\mathrm{MPP}^{+}$condition alone and cotreatment with zVAD-fmk or zIETD-fmk were found to be significantly altered (Fig. $2 C$ ). These deleterious effects of zVADfmk or zIETD-fmk cotreatment could neither be attributed to the caspase inhibitors themselves nor to DMSO, the solvent used for resuspension of the caspase inhibitors, because incubation of primary cultures with caspase inhibitors or DMSO alone did not result in significant neuronal death in the absence of $\mathrm{MPP}^{+}$over $72 \mathrm{hr}$ (zITED-fmk, +0.59\%; zVAD-fmk, -3.13\%; DMSO, $-9.59 \%)$.

\section{Viability of primary DA cultures is further impaired by caspase inhibitors}

To assess the viability of DA neurons, we next examined energydependent $\left[{ }^{3} \mathrm{H}\right] \mathrm{DA}$ uptake at the same time points at which $\mathrm{TH}$ cell counts were performed. At $12 \mathrm{hr}$ (Fig. $3 A$ ), when the number of TH-positive cell bodies was the same in all conditions, a significant decrease in DA uptake could already be observed in cultures treated with $\mathrm{MPP}^{+}$and cultures cotreated with zVADfmk or zIETD-fmk. At 24 hr (Fig. 3B), DA uptake had further decreased in cultures treated with $\mathrm{MPP}^{+}$and in the cultures cotreated with zVAD-fmk or zIETD-fmk compared with controls. At the $72 \mathrm{hr}$ end point, DA uptake had similarly decreased in the $\mathrm{MPP}^{+}$cultures and in the cultures cotreated with zVADfmk compared with control cultures (Fig. 3C). In the zIETD-fmk conditions, DA uptake had dropped even further compared with

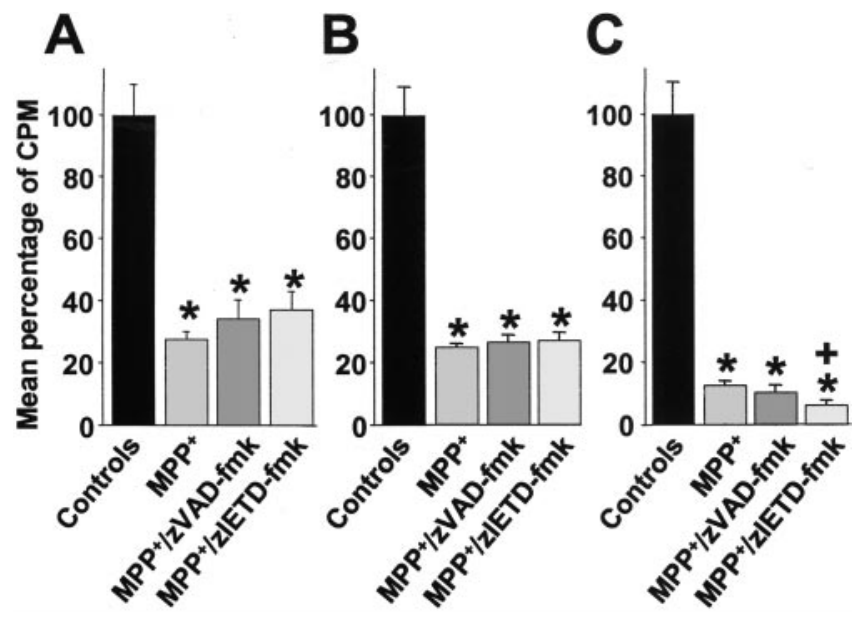

Figure 3. Mean $\left[{ }^{3} \mathrm{H}\right] \mathrm{DA}$ uptake expressed as mean percentage of counts per minute $(C P M)$ in primary cultures of rat mesencephalic neurons. Cultures were treated with $3 \mu \mathrm{M} \mathrm{MPP}{ }^{+}, 3 \mu \mathrm{M} \mathrm{MPP}^{+}$, and $100 \mu \mathrm{M}$ zVAD-fmk, or $3 \mu \mathrm{M} \mathrm{MPP}{ }^{+}$and $100 \mu \mathrm{M}$ zIETD-fmk, and treatments were terminated after $12(A), 24(B)$, and $72(C)$ hr. Mean total counts per minute per control well were $1423 \pm 142(12 \mathrm{hr}), 10419 \pm 2301$ (24 hr), and $6589 \pm 1610(72 \mathrm{hr}) .{ }^{*} p<0.005$ compared with control cultures. $+p<0.05$ compared with $\mathrm{MPP}^{+}$cultures.

controls, which also represented a significant decrease in DA uptake compared with the $\mathrm{MPP}^{+}$condition alone (Fig. $3 C$ ).

\section{Morphology of primary DA cultures treated with caspase inhibitors}

Because the caspase inhibitors used did not prevent the death of DA neurons in primary cultures of mesencephalon, despite the fact that at least caspase- 3 has been shown to mediate cell death in this paradigm (Hartmann et al., 2000), we wondered whether the mode of cell death observed under the use of caspase inhibitors was indeed compatible with apoptosis. To answer this question, we double-stained DA cultures with TH and Hoechst 33258 $72 \mathrm{hr}$ after incubation with $\mathrm{MPP}^{+}$alone or cotreatment with zVAD-fmk or zIETD-fmk. Compared with control cultures (Fig. $4 A, B)$, chromatin condensation was observed in DA neurons treated with $\mathrm{MPP}^{+}$(Fig. 4C,D). Neural cell bodies were also shrunken, and neuritic extensions were lost, suggesting loss of functionality. Under addition of zVAD-fmk, however, the majority of morphologies detected showed preserved chromatin structure (Fig. $4 E$ ), yet the loss of neurites and membrane damage were suggestive of necrosis (Fig. $4 F$ ). After zIETD-fmk cotreatment, mixed figures of necrosis (membrane leakage) (Fig. 4G) and apoptosis (chromatin condensation) (Fig. 4H, arrows) could be observed. However, the extent of these nuclear apoptotic changes was far less marked than after $\mathrm{MPP}^{+}$treatment alone.

\section{Percentage of terminal deoxynucleotidyl transferase- mediated biotinylated UTP nick end labeling-positive DA neurons in primary cultures treated with MPP ${ }^{+}$is decreased in cultures cotreated with caspase inhibitors}

To extend the purely morphological observation that cells do not seem to die by apoptosis in caspase inhibition conditions, we stained primary mesencephalic cultures treated as described previously by terminal deoxynucleotidyl transferase-mediated biotinylated UTP nick end labeling (TUNEL) assay to detect DNA strand breaks. Compared with control cultures, the percentage of TUNEL-positive DA neurons was significantly increased in the 

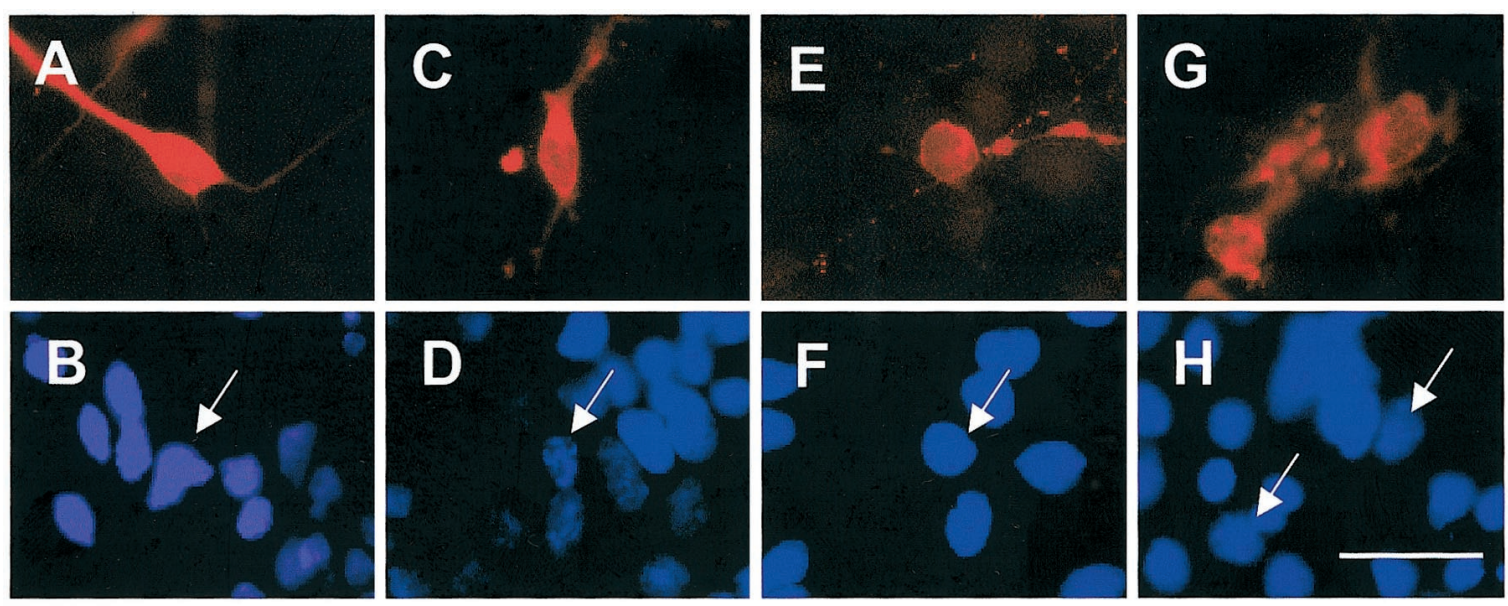

Figure 4. Morphological assessment of immunofluorescent dopaminergic neurons in primary cultures of rat mesencephalic neurons. Cultures were fixed $72 \mathrm{hr}$ after initiation of treatment and stained with a TH monoclonal mouse antibody revealed by TRITC and Hoechst 33258 staining (blue). $A, B$, Control group. TH-positive neurons display a regular cell shape with neurites $(A)$ and intact nucleus in these neurons $\left(B ;\right.$ arrow). $C, D, \mathrm{MPP}^{+}(3 \mu \mathrm{M})$. In contrast, TH-positive neurons treated with $3 \mu \mathrm{M} \mathrm{MPP}{ }^{+}$alone display rounded cell bodies and retracted neurites $(C)$, accompanied by DNA condensation $\left(D\right.$; arrow). $E, F, \mathrm{MPP}^{+}(3 \mu \mathrm{M})$-zVAD-fmk $(100 \mu \mathrm{M})$. Cell bodies also appear rounded with retracted neurites; however, the surrounding $\mathrm{TH}$ fluorescence indicates membrane leakage suggestive of necrosis $(E)$, but the nucleus remains intact $(F ;$ arrow $) . G, H, \mathrm{MPP}^{+}(3 \mu \mathrm{M})-\mathrm{zIETD}$-fmk $(100 \mu \mathrm{M})$. After treatment with $\mathrm{MPP}^{+}-\mathrm{zIETD}-\mathrm{fmk}$, similar images to those obtained under treatment with $\mathrm{MPP}^{+}-\mathrm{zVAD}$-fmk could be observed, yet membrane damage appeared even more pronounced $(G)$. Nuclear morphology is slightly fragmented and thus suggestive of apoptosis $(H$; arrows). Scale bar, $10 \mu \mathrm{m}$

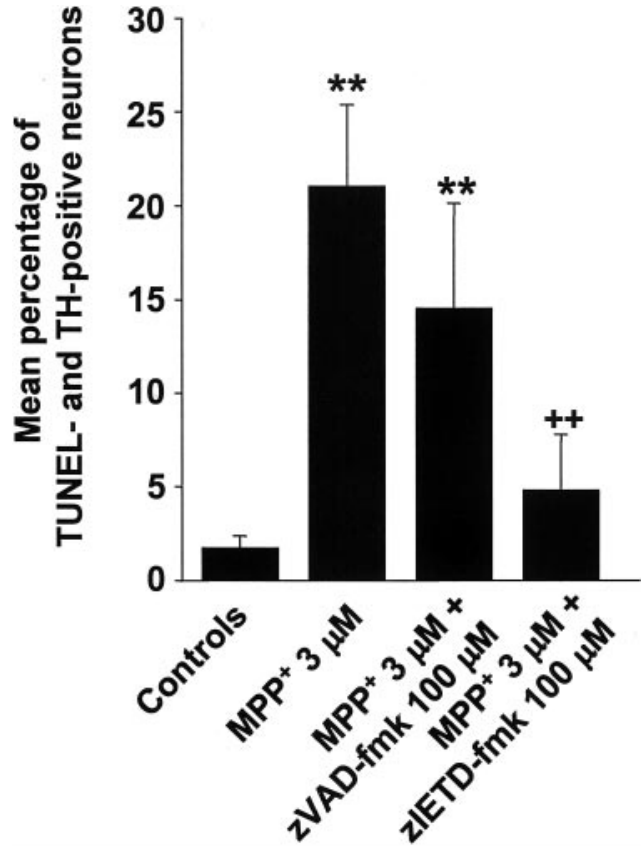

Figure 5. Mean percentage of TUNEL-positive among TH-positive neurons in primary cultures of rat mesencephalic neurons. Cultures were treated with $3 \mu \mathrm{M} \mathrm{MPP}{ }^{+}, 3 \mu \mathrm{M} \mathrm{MPP}{ }^{+}$, and $100 \mu \mathrm{M} \mathrm{zVAD-fmk,} \mathrm{or} 3 \mu \mathrm{M}$ $\mathrm{MPP}^{+}$and $100 \mu \mathrm{M}$ zIETD-fmk, and treatments were terminated after 72 hr. ${ }^{* *} p<0.01$ compared with control cultures. $++p<0.01$ compared with $\mathrm{MPP}^{+}$cultures.

$\mathrm{MPP}^{+}$and $\mathrm{MPP}^{+}-\mathrm{zVAD}-\mathrm{fmk}$ conditions (Fig. 5). This percentage was, however, far less pronounced in the $\mathrm{MPP}^{+}{ }_{-} \mathrm{zVAD}-\mathrm{fmk}$ conditions. Strikingly, there was no statistical difference in TUNEL- and TH-positive neurons between the control and the $\mathrm{MPP}^{+}$-zIETD-fmk condition, whereas there was a significant decrease of TUNEL- and TH-positive neurons in the $\mathrm{MPP}^{+}{ }_{-}$ zIETD-fmk compared with the $\mathrm{MPP}^{+}$condition. The fact that cotreatment with caspase inhibitors decreased the percentage of TUNEL-positive cells is also an indirect indication that caspase inhibitors were indeed active in cell culture conditions.

\section{Intracellular energy levels are severely compromised in} primary DA cultures treated with caspase inhibitors

Because necrosis predominantly occurs in states of intracellular energy depletion (Nicotera et al., 2000), intracellular ATP and ADP levels were measured in our cell culture system at $72 \mathrm{hr}$. Whereas cultures treated with $\mathrm{MPP}^{+}$exhibited a slight but nonsignificant decrease in ATP levels, ATP levels decreased significantly in cultures cotreated with zVAD-fmk or zIETD-fmk (Fig. $6 A)$. Furthermore, ATP levels in cultures treated with $\mathrm{MPP}^{+}$and zIETD-fmk decreased significantly compared with cultures treated with $\mathrm{MPP}^{+}$alone. ADP levels decreased significantly in all conditions compared with control cultures, and the levels of decrease were significantly higher in cultures treated with $\mathrm{MPP}^{+}$ and zIETD-fmk compared with cultures treated with $\mathrm{MPP}^{+}$ alone (Fig. 6B). ADP/ATP ratios were significantly decreased in all conditions compared with controls but did not differ significantly between the $\mathrm{MPP}^{+}$and caspase inhibitor-cotreated cultures (Fig. 6C).

\section{Increase in intracellular glucose confers partial resistance to MPP ${ }^{+}$by caspase inhibitors in primary DA cultures but does not restore cell viability}

When glucose concentrations were raised from 25 to $100 \mathrm{~mm}$, cultures treated with $\mathrm{MPP}^{+}$showed a slight but significant increase in the percentage of TH-positive neurons at $72 \mathrm{hr}$ compared with $\mathrm{MPP}^{+}$-treated cultures at $25 \mathrm{~mm}$ glucose (Fig. 7A). Similarly, cultures cotreated with glucose and zVAD-fmk or zIETD-fmk showed significant protection compared with $\mathrm{MPP}^{+}$ treatment without the addition of glucose. zVAD-fmk treatment also showed a significant increase in the percentage of $\mathrm{TH}$ positive neurons compared with $\mathrm{MPP}^{+}$-glucose-treated cultures, whereas the increased percentage of TH-positive neurons observed in glucose-zIETD-fmk-treated cultures failed to reach 


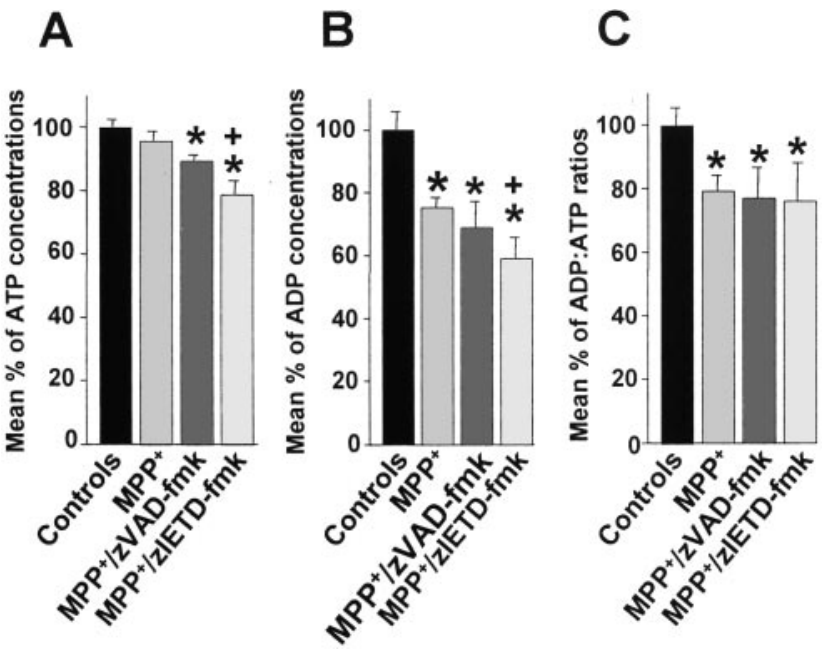

Figure 6. Mean ATP concentrations $(A)$, mean ADP concentrations $(B)$, and mean $\mathrm{ADP} / \mathrm{ATP}$ ratios $(C)$ in primary cultures of rat mesencephalic neurons. Cultures were treated with $3 \mu \mathrm{M} \mathrm{MPP}{ }^{+}, 3 \mu \mathrm{M} \mathrm{MPP}{ }^{+}$, and

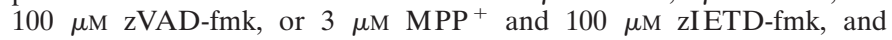
treatments were terminated after $72 \mathrm{hr} .{ }^{*} p<0.05$ compared with control cultures. $+p<0.05$ compared with $\mathrm{MPP}^{+}$cultures.
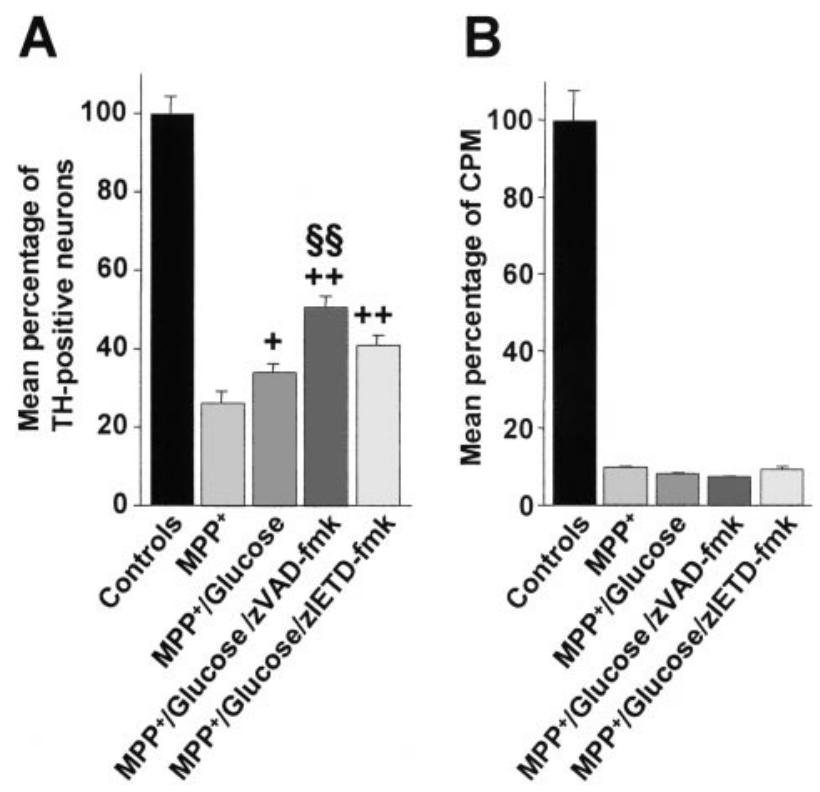

Figure 7. Mean percentage of TH-positive neurons $(A)$ and mean $\left[{ }^{3} \mathrm{H}\right] \mathrm{DA}$ uptake $(B)$ expressed as counts per minute $(C P M)$ in primary cultures of rat mesencephalic neurons treated with $3 \mu \mathrm{M} \mathrm{MPP}{ }^{+}, 3 \mu \mathrm{M}$ $\mathrm{MPP}^{+}-100 \mathrm{~mm}$ glucose, $3 \mu \mathrm{M} \mathrm{MPP}^{+}-100 \mathrm{~mm}$ glucose, and $100 \mu \mathrm{M}$ zVAD-fmk, or $3 \mu \mathrm{M} \mathrm{MPP}{ }^{+}-100 \mathrm{~mm}$ glucose and $100 \mu \mathrm{M}$ zIETD-fmk and fixed after $72 \mathrm{hr}$. Mean total number of TH-positive neurons per control well were $1128 \pm 38.4$, and total number of counts per minute per control well were $46825 \pm 3649 .+p<0.05 ;++p<0.001$ compared with $\mathrm{MPP}^{+}$ cultures with $25 \mathrm{~mm}$ glucose. $\S \S p<0.001$ compared with $\mathrm{MPP}^{+}-100 \mathrm{mM}$ glucose.

statistical significance compared with $\mathrm{MPP}^{+}$-glucose-treated cultures. However, neurons treated with caspase inhibitors showed the same alteration in morphology as neurons under the other $\mathrm{MPP}^{+}$conditions (Fig. 4E-- $H$ ). We therefore assessed the functionality of these neurons by measuring $\left[{ }^{3} \mathrm{H}\right] \mathrm{DA}$ uptake. DA uptake did not differ significantly in $\mathrm{MPP}^{+}$-treated neurons, regardless of glucose and caspase inhibitor treatment (Fig. 7B).

\section{DISCUSSION}

\section{Caspase- 8 activation in melanized DA neurons is almost exclusively observed in PD SNpc}

Overall, the percentage of DA neurons immunoreactive for activated caspase- 8 was exceedingly small in both the PD and control groups. In the PD subjects, an average of $0.0145 \%$ of DA neurons stained for activated caspase- 8 were detected. This percentage, in contrast to the $6.5 \%$ reported for activated caspase- 3 in PD DA SNpc neurons (Hartmann et al., 2000), may well correlate with the primary disease process instead of with perimortem factors, such as hypoxia. The finding that norepinephrine-containing neurons in the LC, which display Lewy bodies and a cell loss of 20-30\% in advanced PD, are immunoreactive for activated caspase- 8 in neither the control nor in the PD group underlines the specificity of caspase- 8 activation in the target region of PD pathology, namely the SNpc. Finally, it cannot be ruled out that L-DOPA treatment, to which all PD patients included in this study were submitted, may contribute to DA cell death, as suggested by in vitro studies (Melamed et al., 1998). However, in vivo, the picture that chronic L-DOPA treatment may even have neuroprotective effects is now predominant (Agid et al., 1999), and it thus appears highly unlikely that caspase- 8 activation might be related to the antiparkinsonian medication used.

\section{Caspase-8 activation is associated with MPTP-induced DA cell death}

In SNpc homogenates from mice subchronically intoxicated with MPTP, a significantly increased release of activated caspase- 8 compared with controls was observed $1 \mathrm{~d}$ after intoxication. This finding suggests that caspase- 8 activation is induced by MPTP and correlates with cell demise in this PD model, because the maximum number of apoptotic figures can be observed at day 1 after intoxication (Tatton and Kish, 1997). These findings also suggest that caspase- 8 activation precedes DA cell death, because MPTP-induced death of DA neurons can be observed up to $7 \mathrm{~d}$ of the end of a subchronic intoxication regimen (Tatton and Kish, 1997). The increase of $18.2 \%$ in the MPTP-treated group compared with the control group was far less pronounced than might be expected from the human postmortem results using the SK440 antibody. However, it must be considered that the percentage of DA neurons present in SNpc homogenates is low. Moreover, within this fraction, only a subset of DA neurons undergo apoptosis and potential caspase- 8 activation at a given time point. Thus, the ability to detect significant differences between the two groups rather suggests that caspase- 8 activation in nigral DA neurons is a potent process after exposure to MPTP-MPP ${ }^{+}$. However, the immunohistochemical results from SK440 staining in the mouse SNpc suggests that caspase-8 activation in DA neurons contributes only partially to the differences observed between control and MPTP mice in the caspase activation assays. It is rather likely that the inflammatory reaction mediated by glial cells after MPTP treatment (Kurkowska-Jastrzebska et al., 1999) involves activation in subpopulations of reactive astroglia and microglial cells and requires caspase- 8 activation for termination of the inflammatory response as described in the immune system (O'Flaherty et al., 2000). Regarding the mechanism of caspase-8 activation in DA neurons after treatment with MPTP-MPP ${ }^{+}$, the most likely explanation involves caspase- 8 cleavage downstream of mitochondrial cytochrome c release (Granville et al., 1998; Slee et al., 1999). More speculatively, radical oxygen species, as generated after MPTP-MPP ${ }^{+}$exposure (Sriram et al., 1997), might trigger transcriptional regulation of TNF- $\alpha$ expres- 


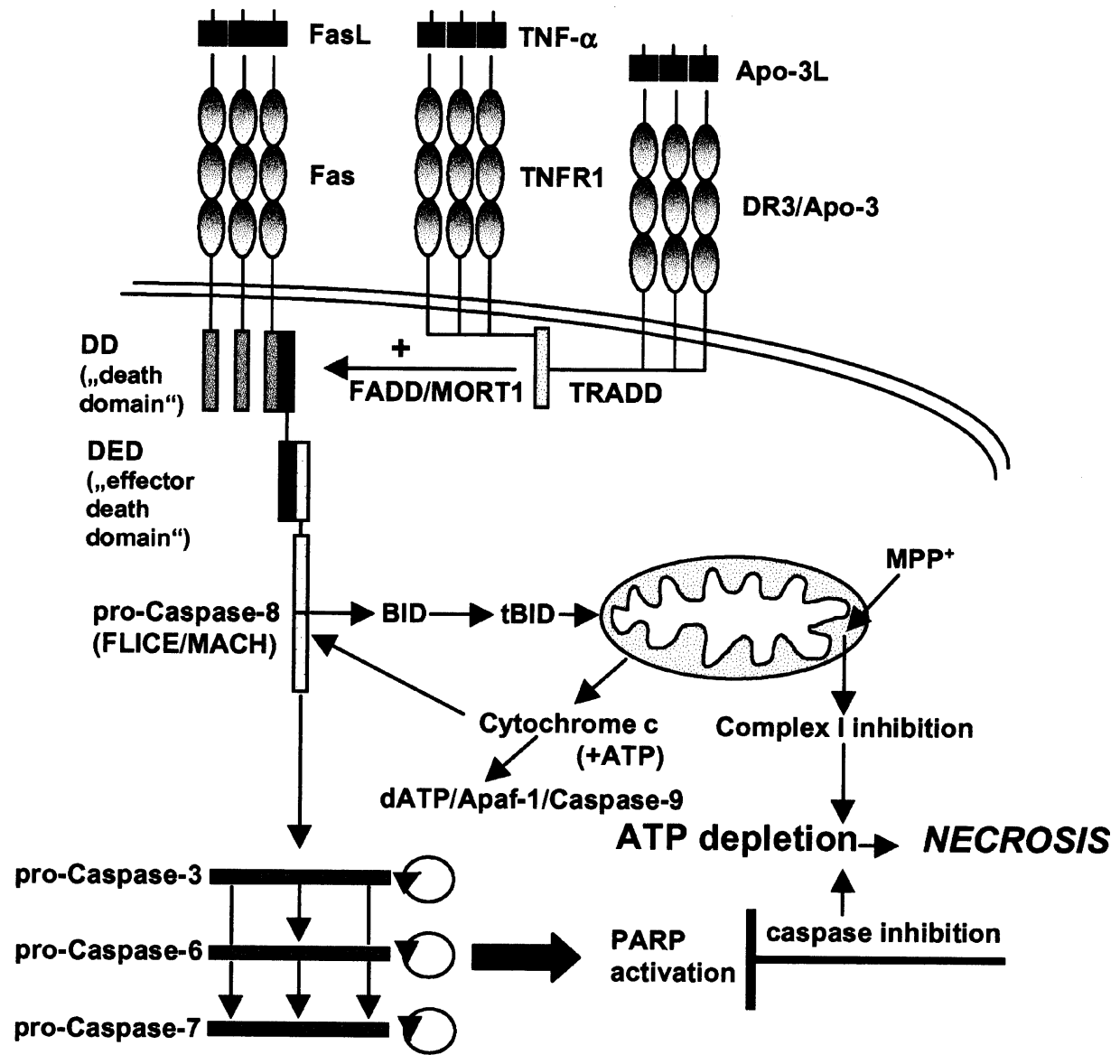

Figure 8. Proposed model for the synergistic effects by $\mathrm{MPP}^{+}$and caspase inhibition. $\mathrm{MPP}^{+}$ inhibits complex I of the mitochondrial respiratory chain, whereas caspase inhibitors preserve PARP activation by blocking its cleavage. Complex I inhibition leads to a direct depletion of ATP. Overactivation of PARP, a nuclear enzyme activated by DNA strand breaks and participating in DNA repair, leads to depletion of the substrate of the enzyme, $\mathrm{NAD}^{+}$, and subsequent ATP depletion through the attempts by the cell to resynthesize $\mathrm{NAD}^{+}$. ATP depletion prevents completion of the apoptotic program because it is a necessary cofactor for caspase-9 activation. An ATP-depleted cell that is lethally metabolically impaired but unable to die by apoptosis switches to a necrotic form of cell death. Apaf-1, Apoptosis protease activating factor; $D R 3$, death receptor-3; FLICE, Fasassociated death domain-like IL-1 $\beta$ converting enzyme; $M A C H$, Mort1-associated CED3 homolog. sion and subsequent caspase- 8 activation, as has been shown for Fas ligand in some cell systems, including microglia (Bauer et al., 1998; Vogt et al., 1998).

\section{Caspase inhibition did not protect DA neurons from undergoing MPP ${ }^{+}$-induced apoptosis in our study}

Recent data have suggested that caspase inhibitors, i.e., zVADfmk, and a relatively specific inhibitor of caspase-3, z-Asp-GluVal-Asp-fluoromethylketone, protect DA neurons against lowdose $\mathrm{MPP}^{+}$toxicity (Dodel et al., 1998). In contrast to our study, Dodel et al. (1998) intoxicated their cultures $24 \mathrm{hr}$ after harvest. At this time point, however, the dopamine transporter is only expressed at very low levels (Michel et al., 1997), suggesting that, under these conditions, $\mathrm{MPP}^{+}$acts through a distinct mechanism, namely indirect glutamate toxicity (Murphy et al., 1990), in which inhibition of mitochondrial function is not the primary mode of cell death. Indeed, cerebellar granular neurons, in which cell death induced by $\mathrm{MPP}^{+}$has been related to autocrine excitotoxic mechanisms, may well respond to caspase inhibition (Du et al., 1997; Leist et al., 1998). Another recent study, however, found no evidence of protection of DA neurons against low-concentration $\mathrm{MPP}^{+}$using the broad-spectrum caspase inhibitor Boc-(Asp)-fluoromethylketone, and suggested that neurons die by a nonapoptotic mechanism in this paradigm (Lotharius et al., 1999).

In contrast to these previous studies, we not only found that caspase inhibitors did not protect DA cultures against $\mathrm{MPP}^{+}$ toxicity, but even seemed to enhance the toxic properties of $\mathrm{MPP}^{+}$with regard both to TH cell count and $\left[{ }^{3} \mathrm{H}\right] \mathrm{DA}$ uptake. Because caspase inhibitors do not exhibit toxic effects in DA cultures without the addition of $\mathrm{MPP}^{+}$, our assumption was that the form of cell death induced by the concomitant treatment of DA cultures with $\mathrm{MPP}^{+}$and caspase inhibitors must be shifted from apoptosis toward necrosis and linked to ATP depletion (Fig. 8), because ATP levels have been shown to be critical in determining whether the cell will die by necrosis or apoptosis (Nicotera et al., 2000). Indeed, $\mathrm{MPP}^{+}$mediates its toxicity through inhibition of complex I of the mitochondrial respiratory chain, eventually resulting in intracellular ATP depletion (Leonard and Schapira, 2000). Similarly, caspase inhibitors indirectly lead to ATP depletion through inhibition of poly(ADP-ribose) polymerase (PARP) cleavage (Ha and Snyder, 1999). PARP is a nuclear enzyme activated by DNA strand breaks and participates in DNA repair. Overactivation of PARP after cellular insults leads to necrotic cell death by depletion of the substrate of the enzyme, $\beta$-nicotinamine $\left(\mathrm{NAD}^{+}\right)$, and subsequently ATP depletion through the attempts by the cell to resynthesize $\mathrm{NAD}^{+}$(Ha and Snyder, 1999). Conversely, PARP is a preferential substrate for caspases, which thus enables the caspase cascade to perpetuate itself by preserving intracellular ATP concentrations. Accordingly, several groups have described a switch of apoptosis to necrosis after the use of caspase inhibitors (Eguchi et al., 1997; Hirsch et al., 1997; Lemaire et al., 1998, 1999; Vercammen et al., 1998a,b; Samali et al., 1999; Tanabe et al., 1999).

Indeed, apoptotic figures could be readily detected in DA cultures treated with $\mathrm{MPP}^{+}$alone, whereas the morphological changes observed in the cultures cotreated with caspase inhibitors were compatible with necrosis with regard to membrane leakage. Chromatin structure in these damaged neurons was either intact 
or condensed, thus suggesting mixed forms of apoptosis-necrosis. Also, the percentage of TUNEL- and TH-positive neurons was decreased after $\mathrm{MPP}^{+}$intoxication and cotreatment with caspase inhibitors compared with $\mathrm{MPP}^{+}$alone, although the rate of cell loss was not affected by caspase inhibition, suggesting that apoptosis was not the mode of cell death involved. Furthermore, ATP and ADP levels were significantly reduced after treatment with $\mathrm{MPP}^{+}$, as well as with cotreatment using caspase inhibitors. However, the decrease in intracellular energy levels was more profound after caspase inhibition, thus supporting the notion that caspase inhibition contributes to energy depletion in this model. Interestingly, ATP levels decreased especially after cotreatment with zIETD-fmk, thus correlating with the particularly marked decrease in TH cell count, TUNEL-positive neurons, and [ $\left.{ }^{3} \mathrm{H}\right] \mathrm{DA}$ uptake observed under this condition. A possible explanation may involve the key role of caspase- 8 in maintaining mitochondrial cytochrome c release into the cytosol, because inhibition of complex I by $\mathrm{MPP}^{+}$induces opening of mitochondrial transition pores with cytochrome c release and subsequent caspase activation (Cassarino et al., 1999), which may be upheld even more efficiently in the event of caspase- 8 inhibition. However, nuclear changes suggestive of apoptosis (condensationfragmentation) were more readily detected in zIETD-fmkcotreated cultures, which is in line with a more limited spectrum of caspase inhibition than zVAD-fmk, which, moreover, is also able to inhibit a number of noncaspase proteases, including several cathepsins (Yamashima, 2000).

Finally, in the presence of high glucose concentrations, partial protection of DA cultures against $\mathrm{MPP}^{+}$was achieved through caspase inhibitors. This protection was less marked after zIETDfmk administration, in accordance with its particularly deleterious effects under conditions of lower glucose concentrations. However, caspase inhibition did not affect $\left[{ }^{3} \mathrm{H}\right] \mathrm{DA}$ uptake as an index of neuronal functionality. Indeed, it has been suggested that, although caspase inhibition may block the morphological manifestations of apoptosis, cell viability and functionability are not affected in cells morphologically preserved by inhibition of the apoptotic cascade (Werth et al., 2000). Indeed, the present data favor apoptosis as an appropriate process, helping to eliminate adult neurons that are not salvageable because of severe metabolic impairment. In contrast to this situation, healthy embryonic nigral tissue pretreated with caspase inhibitors showed a dramatically increased survival and functionality after transplantation in hemiparkinsonian rats (Schierle et al., 1999).

It must be underlined that a sharp distinction of apoptosis versus necrosis is very problematic in pathological, i.e., nondevelopmental settings. After neurological insults, the mode of cell death may be mechanistically identical to classical developmental apoptosis with regard to the intracellular transduction pathways involved, but completion of the apoptotic program may be incomplete and/or morphological features of apoptosis and necrosis may co-occur (Roy and Sapolsky, 1999). This proposition is underlined by mixed forms of necrotic-apoptosis occasionally observed in caspase inhibitor-treated cultures. In the context of the present study, the term "necrotic" is used as a synonymous for "nonapoptotic" cell death. Although such a choice may not be appropriate on purely morphological grounds, it may be helpful to suggest two facts: (1) that this mode of cell death is unresponsive to pharmacological manipulation by anti-apoptotic agents, i.e., caspase inhibitors, and (2) that the ensuing cell death is likely to be associated at least with leakage of the extracellular membrane and subsequent inflammatory phenomena in surrounding tissue typical of necrosis, which are not observed in purely apoptotic cell death.

In conclusion, the present data, which need to be confirmed in vivo, favor a cautious approach to using caspase inhibitors in the treatment of PD.

\section{REFERENCES}

Agid Y, Ahlskog E, Albanese A, Calne D, Chase T, De Yebenes J, Factor S, Fahn S, Gershanik O, Goetz C, Koller W, Kurth M, Lang A, Lees A, Lewitt P, Marsden D, Melamed E, Michel PP, Mizuno Y, Obeso J, Oertel W, Olanow W, Poewe W, Pollak P, Przedborski S, Quinn N, Raisman-Vozari R, Rajput A, Stocchi F, Tolosa E (1999) Levodopa in the treatment of Parkinson's disease: a consensus meeting. Mov Disord 14:911-913.

Bauer MKA, Vogt M, Los M, Siegel J, Wesselborg S, Schulze-Osthoff K (1998) Role of reactive oxygen intermediates in activation-induced CD95 (APO-1/Fas) ligand expression. J Biol Chem 273:8048-8055.

Boka G, Anglade P, Wallach D, Javoy-Agid F, Agid Y, Hirsch EC (1994) Immunocytochemical analysis of tumor necrosis factor and its receptors in Parkinson's disease. Neurosci Lett 172:151-154.

Cassarino DS, Parks JK, Parker Jr WD, Bennett Jr JP (1999) The parkinsonian neurotoxin $\mathrm{MPP}^{+}$opens the mitochondrial permeability transition pore and releases cytochrome $\mathrm{c}$ in isolated mitochondria via an oxidative mechanism. Biochem Biophys Acta 1453:49-62.

Dodel RC, Du Y, Bales KR, Ling ZD, Carvey PM, Paul SM (1998) Peptide inhibitors of caspase-3-like proteases attenuate 1-methyl-4phenylpyridium-induced toxicity of cultured fetal rat mesencephalic dopamine neurons. Neuroscience 86:701-707.

Dodel RC, Du Y, Bales KR, Ling ZD, Carvey PM, Paul SM (1999) Caspase-3-like proteases and 6-hydroxydopamine induced cell death. Brain Res Mol Brain Res 64:141-148.

Du Y, Dodel RC, Bales KR, Jemmerson R, Hamilton-Byrd E, Paul SM (1997) Involvement of a caspase-3-like cysteine protease in 1-methyl4-phenylpyridinium-mediated apoptosis of cultured cerebellar granule neurons. J Neurochem 1997:1382-1388.

Eguchi Y, Shimizu S, Tsujimoto Y (1997) Intracellular ATP levels determine cell death fate by apoptosis or necrosis. Cancer Res 57:1835-1840.

Franke B, Bayatti N, Engele J (2000) Neurotrophins require distinct extracellular signals to promote the survival of CNS neurons in vitro. Exp Neurol 165:125-135.

Garcia-Calvo M, Peterson EP, Leiting B, Ruel R, Nicholson DW, Thornberry NA (1998) Inhibition of human caspases by peptide-based and macromolecular inhibitors. J Biol Chem 273:32608-32613.

Granville DJ, Carthy CM, Jiang H, Shore GC, McManus BM, Hunt DW (1998) Rapid cytochrome c release, activation of caspases 3, 6, 7 and 8 followed by Bap31 cleavage in HeLa cells treated with photodynamic therapy. FEBS Lett 437:5-10.

Green DR (1998) Apoptotic pathways: the roads to ruin. Cell 94:695-698.

Ha CH, Snyder SH (1999) Poly(ADP-ribose) polymerase is a mediator of necrotic cell death by ATP depletion. Proc Natl Acad Sci USA 96:13978-13982

Hartley A, Stone JM, Heron C, Copper JM, Shapira AHV (1994) Complex I inhibitors induce dose-dependent apoptosis in PC12 cells: relevance to Parkinson's disease. J Neurochem 63:1987-1990.

Hartmann A, Hirsch EC (2000) The apoptosis theory in Parkinson's disease-revisited. Adv Neurol 86:143-153.

Hartmann A, Hunot S, Michel PP, Muriel MP, Vyas S, Faucheux BA, Mouatt-Prigent A, Turmel H, Srinivasan A, Ruberg M, Evan GI, Agid Y, Hirsch EC (2000) Caspase-3: a vulnerability factor and a final effector in the apoptotic death of dopaminergic neurons in Parkinson's disease. Proc Natl Acad Sci USA 97:2875-2880.

Hirsch EC, Graybiel AM, Agid Y (1988) Melanized dopaminergic neurons are differentially susceptible to degeneration in Parkinson's disease. Nature 334:345-348.

Hirsch T, Marchetti P, Susin SA, Dallaporta B, Zamzami N, Marzo I, Geuskens M, Kroemer G (1997) The apoptosis-necrosis paradox. Apoptogenic proteases activated after mitochondrial permeability transition determine the mode of cell death. Oncogene 15:1573-1581.

Hunot S, Brugg B, Ricard D, Michel PP, Muriel MP, Ruberg M, Faucheux BA, Agid Y, Hirsch EC (1997) Nuclear translocation of NFkappaB is increased in dopaminergic neurons of patients with Parkinson's disease. Proc Natl Acad Sci USA 94:7531-7536.

Hunot S, Dugas N, Faucheux B, Hartmann A, Tardieu M, Debré P, Agid Y, Dugas B, Hirsch EC (1999) FceRII/CD23 is expressed in Parkinson's disease and induces, in vitro, production of nitric oxide and TNF-a expression in glial cells. J Neurosci 19:3440-3447.

Kurkowska-Jastrzebska I, Wronska A, Kohutnicka M, Czlonkowski A, Czlonkowska A (1999) The inflammatory reaction following 1-methyl-4-phenyl-1,2,3,6-tetrahydropyridine intoxication in mouse. Exp Neurol 156:50-61. 
Leist M, Volbracht C, Fava E, Nicotera P (1998) 1-Methyl-4-phenylpyridinium induces autocrine excitoxicity, protease activation and neuronal apoptosis. Mol Pharmacol 54:789-801.

Lemaire C, Andreau K, Souvannavong V, Adam A (1998) Inhibition of caspase activity induces a switch from apoptosis to necrosis. FEBS Lett 425:266-270.

Lemaire C, Andreau K, Fraisse CS, Adam A, Souvannavong V (1999) IL-4 inhibits apoptosis and prevents mitochondrial damage without inducing the switch to necrosis observed with caspase inhibitors. Cell Death Differ 6:813-820.

Leonard JV, Schapira AH (2000) Mitochondrial respiratory chain disorders. II. Neurodegenerative disorders and nuclear gene defects. Lancet 355:389-394.

Lotharius J, Dugan LL, O’Malley KL (1999) Distinct mechanisms underlie neurotoxin-mediated cell death in cultured dopaminergic neurons. J Neurosci 19:1284-1293.

Marsden CD, Olanow CW (1998) The causes of Parkinson's disease are being unraveled and rational neuroprotective therapy is close to reality. Ann Neurol 44:S189-S196.

Melamed E, Offen D, Shirvan A, Djaldetti R, Barzilai A, Ziv I (1998) Levodopa toxicity and apoptosis. Ann Neurol [Suppl 1] 44:S149-S154.

Michel PP, Agid Y (1992) The glutamate antagonist, MK-801, does not prevent dopaminergic cell death induced by the 1-methyl-4phenylpyridinium ion $\left(\mathrm{MPP}^{+}\right)$. Brain Res 597:233-240.

Michel PP, Agid Y (1996) Chronic activation of the cyclic AMP signaling pathway promotes development and long-term survival of mesencephalic dopaminergic neurons. J Neurochem 67:1633-1642.

Michel PP, Ruberg M (1999) Ventral mesencephalic (dopaminergic) and septal cholinergic neurons. In: The neuron in tissue culture, Vol 18 (Haynes L, ed), pp 503-510. IBRO handbook series. New York: Wiley.

Michel PP, Ruberg M, Agid Y (1997) Rescue of mesencephalic dopamine neurons by anticancer drug cytosine arabinoside. J Neurochem 69:1499-1507.

Mochizuki H, Nakamura N, Nishi K, Mizuno Y (1994) Apoptosis induced by 1-methyl-4-phenylpyridinium ion (MPP+) in ventral mesencephalic striatal co-culture in rat. Neurosci Lett 170:191-194.

Mogi M, Harada M, Riederer P, Narabayashi H, Fujita K, Nagatsu T (1994) Tumor necrosis factor-alpha (TNF-alpha) increases both in the brain and in the cerebrospinal fluid from parkinsonian patients. Neurosci Lett 165:208-210.

Mogi M, Togari A, Kondo T, Mizuno Y, Komure O, Kuno S, Ichinose H, Nagatsu T (2000) Caspase activities and tumor necrosis factor receptor R1 (p55) level are elevated in the substantia nigra from parkinsonian brain. J Neural Transm 107:335-341.

Murphy TH, Schnaar RL, Coyle JT (1990) Immature cortical neurons are uniquely sensitive to glutamate toxicity by inhibition of cystine uptake. FASEB J 4:1624-1633.

Nicotera P, Leist M, Fava E, Berliocchi L, Volbracht C (2000) Energy requirement for caspase activation and neuronal cell death. Brain Pathol 10:276-282.

Ochu EE, Rothwell NJ, Waters CM (1998) Caspases mediate 6-hydoxydopamine-induced apoptosis but not necrosis in PC12 cells. J Neurochem 70:2637-2640.

O'Flaherty E, Wong WK, Pettit SJ, Seymour K, Ali S, Kirby JA (2000) Regulation of T-cell apoptosis: a mixed lymphocyte reaction model. Immunology 100:289-299.

Roy M, Sapolsky R (1999) Neuronal apoptosis in acute necrotic insults: why is this subject such a mess? Trends Neurosci 22:419-422.

Samali A, Nordgren H, Zhivotovsky B, Peterson E, Orrenius S (1999) A comparative study of apoptosis and necrosis in HepG2 cells: oxidant- induced caspase inactivation leads to necrosis. Biochem Biophys Res Commun 255:6-11.

Schierle GS, Hansson O, Leist M, Nicotera P, Widner $\mathrm{H}$, Brundin P (1999) Caspase inhibition reduces apoptosis and increases survival of nigral transplants. Nat Med 5:97-100.

Schulze-Osthoff K, Ferrari D, Los M, Wesselborg S, Peter ME (1998) Apoptosis signaling by death receptors. Eur J Biochem 254:439-459.

Slee EA, Harte MT, Kluck RM, Wolf BB, Casiano CA, Newmeyer DD, Wang HG, Reed JC, Nicholson DW, Alnemri ES, Green DR, Martin SJ (1999) Ordering the cytochrome c-initiated caspase cascade: hierarchical activation of caspases-2, -3, -6, -7, -8, and -10 in a caspase-9dependent manner. J Cell Biol 144:281-292.

Spampinato U, Gozlan H, Daval G, Fattaccini CM, Hamon M (1988) Dopamine receptor subsensitivity in the substantia nigra after chronic morphine treatment in rats. Eur J Pharmacol 150:113-122.

Spooren WPJM, Gentsch C, Wiessner C (1998) TUNEL-positive cells in the substantia nigra of C57BL/6 mice after a single bolus of 1-methyl4-phenyl-1,2,3,6-tetrahydropyridine. Neuroscience 85:649-651.

Sriram K, Pai KS, Boyd MR, Ravindranath V (1997) Evidence for generation of oxidative stress in brain by MPTP: in vitro and in vivo studies in mice. Brain Res 749:44-52.

Takai N, Nakamishi H, Tanabe K, Nishioku T, Sugiyama T, Fujiwara M, Yamamoto K (1998) Involvement of caspase-like proteinases in apoptosis of neuronal PC12 cells and primary cultured microglia induced by 6-hydroxydopamine. J Neurosci Res 54:214-222.

Tanabe K, Nakanishi H, Maeda H, Nishioku T, Hashimoto K, Liou SY, Akamine A, Yamamoto K (1999) A predominant apoptotic death pathway of neuronal PC12 cells induced by activated microglia is displaced by a non-apoptotic death pathway following blockage of caspase-3-dependent cascade. J Biol Chem 274:15725-15731.

Tatton NA, Kish S (1997) In situ detection of apoptotic nuclei in the substantia nigra compacta of 1-methyl-4-phenyl-1,2,3,6-tetrahydropyridine-treated mice using terminal deoxynucleotidyl transferase labelling and acridine orange staining. Neuroscience 77:1037-1048.

Velier JJ, Ellison JA, Kikly K, Spera PA, Barone FC, Heurstein GZ (1999) Caspase-8 and caspase-3 are expressed by different populations of cortical neurons undergoing delayed cell death after focal stroke in the rat. J Neurosci 19:5932-5941.

Vercammen D, Brouckaert G, Denecker G, Van de Craen M, Declercq W, Fiers W, Vandenabeele P (1998a) Dual signaling of the Fas receptor: initiation of both apoptotic and necrotic cell death pathways. J Exp Med 188:919-930.

Vercammen D, Beyaert R, Denecker G, Goossens V, Van Loo G, Declercq W, Grooten J, Fiers W, Vandenabeele P (1998b) Inhibition of caspases increases the sensitivity of L929 cells to necrosis mediated by tumor necrosis factor. J Exp Med 187:1477-1485.

Vogt M, Bauer MK, Ferrari D, Schulze-Osthoff K (1998) Oxidative stress and hypoxia/reoxygenation trigger CD95 (APO-1/Fas) ligand expression in microglial cells. FEBS Lett 429:67-72.

Werth JL, Deshmukh M, Cocabo J, Johnson Jr EM, Rothman SM (2000) Reversible physiological alterations in sympathetic neurons deprived of NGF but protected from apoptosis by caspase inhibition or Bax deletion. Exp Neurol 161:203-211.

Whiteside G, Munglani R (1998) TUNEL, Hoechst and immunohistochemistry triple-labelling: an improved method for detection of apoptosis in tissue sections-an update. Brain Res Brain Res Protoc 3:52-53.

Yamashima T (2000) Implication of cysteine proteases calpain, cathepsin and caspase in ischemic neuronal death of primates. Prog Neurobiol 62:273-295. 